\title{
FORMULASI ETIKA BISNIS HALAL THAYYIB \\ DALAM PERSPEKTIF MAQASHID SYARIAH \\ KONTEMPORER JASSER AUDA
}

\author{
Nur Chanifah \\ Fakultas Hukum Universitas Brawijaya \\ J1. MT Haryono 169 Malang \\ Email:nur.chanifah@ub.ac.id
}

\begin{abstract}
This study aims to find the formulation of thayyib halal business ethics in the perspective of contemporary maqashid syaria. In Indonesia there are many fraudulent investments under the guise of syari'ah. In fact, Islamic business has the principle of a halal thayyib business that prioritizes the benefit and prosperity of every creature as a form of implementing maqashid sharia. Therefore, it is important to study this problem so that business ethics can be more contextual with current conditions. This research is included in normative research with a conceptual approach and an analytical approach. The data collection method uses literature review. While the research data analysis using descriptive-qualitative. The results show that: first, the formulation of the halal thayyib business in the perspective of Jasser Auda's contemporary maqashid syari'ah is a description of one of the maqashid sharia, namely to maintain and fulfill the desire and benefit of wealth (hifdzul mal). This concept can be viewed in terms of how to get it or in terms of maintaining the property that is already owned. Second, halal thayyib business ethics includes the prohibition on containing elements of usury, gharar, maisir, ihtikar, and bai' najasy'. Meanwhile, the Maqashid sharia is to avoid the practice of tyranny against business people, to avoid gharar in buying and selling transactions so that it is free from fade, loss, and injustice in business transactions, avoiding laziness from work due to dreams and speculation, and to avoid "false requests". which can cause loss or injustice.
\end{abstract}

Keywords:Business Ethic, Halal Ethic, Maqashid Syariah

\begin{abstract}
Abstrak
Penelitian ini bertujuan untuk menemukan formulasi etika bisnis halal thayyib dalam perspektif maqashid syariah kontemporer. Dalam prakteknya di Indonesia banyak ditemukan investasi bodong yang berkedok syari'ah. Padahal, bisnis syari'ah berprinsip pada bisnis yang halal thayyib yang mengutamakan kebaikan atau kemaslahatan manusia sebagai wujud pelaksanaan maqashid al-syariah. Oleh karena itu, maka penting diadakan kajian tersebut agar etika bisnis bisa lebih konstektual dengan kondisi saat ini. Penelitian ini merupakan penelitian normatif dengan pendekatan konseptual (conceptual approach). Metode pengumpulan bahannya dengan telaah kepustakaan. Sedangkan analisis bahan penelitian menggunakan deskriptif-kualitatif. Hasil Penelitian Menunjukkan bahwa: pertama, formulasi bisnis halal thayyib dalam perspektif maqashid syari'ah kontemporer Jasser Auda merupakan penjabaran dari salah satu maqashid syariah, yaitu untuk menjaga dan memenuhi hajat dan maslahat akan harta (hifdzul mal). Konsep tersebut bisa ditinjau dari segi bagaimana mendapatkannya atau dari segi memelihara harta yang sudah dimiliki. Kedua, etika bisnis halal thayyib meliputi adanya larangan mengandung


unsur riba, gharar, maisir, ihtikar, dan bai' najasy'. Sedangkan Maqashidsyariahnya adalah untuk menghindari terjadinya praktek kezaliman terhadap pelaku bisnis, menghindari praktek gharar pada transaksi jual beli sehingga bebas dari kemudaratan, kerugiaan, ketidak adilan dan kezaliman dalam transaksi bisnis, menjauhkan dari sifat malas bekerja karena hanya tergantung pada angan-angan dan spekulasi saja, dan untuk menghindari terjadinya permintaan palsu yang dapat menyebabkan kerugian atau kezaliman.

Kata kunci: Etika Bisnis, Halal Thayyib, Maqashid Syariah

\section{Latar Belakang}

Kegiatan ekonomi sebenarnya merupakan kegiatan manusia. Manusia adalah pemeran utama sekaligus agen dalam ekonomi. Manusia berperan sebagai aktor intelektual yang menentukan alur cerita bisnis masa depan. Oleh karena itu, segala keputusan tentang bisnis dipertimbangkan dan diputuskan di tangan manusia. Dengan kata lain, kegiatan bisnis merupakan cermin atau representasi kehidupan manusia. Dalam kegiatan bisnis, manusia dapat menemukan berbagai watak, karakter dan kepribadian hidup manusia. Kepribadian manusia seperti jujur, adil, ramah, cermat, disiplin, kerja keras, dan pantang menyerah sering ditemukan juga dalam kegiatan berbisnis yang secara langsung juga menjadi karakter khas pelaku bisnis. Hal ini sebenarnya menunjukkan korelasi yang sangat erat antara transaksi dalam bisnis dengan kehidupan sehari-hari seseorang. ${ }^{1}$

Bisnis yang terlahir dari kegiatan manusia untuk memenuhi kebutuhan hidup seharusnya mampu membawa manusia pada tujuan hidup yang mendasar. Hal ini bisa dicapai apabila dalam berbisnis mempertimbangkan etika dalam seluruh aktivitasnya. Bisnis membutuhkan etika sebagai sarana sekaligus landasan dalam berbisnis. Oleh karena itu, etika diperlukan sebagai instrumen yang diperlukan untuk mengembalikan kegiatan bisnis manusia agar dapat mewujudkan kesejahteraan manusia.

Dalam prakteknya di Indonesia banyak ditemukan investasi bodong yang berkedok syari'ah. Hal ini sebagaimana dirilis oleh kontan co.id yang mejelaskan bahwa berbagai modus dilakukan pelaku penipuan untuk mengelabui masyarakat dengan bisnis properti berdasarkan prinsip syariah. Dengan imingiming syariah syariah, maka banyak yang tertarik beli. Misalnya kasus PT Wepro Citra Sentosa yang menipu 3.680 orang di beberapa wilayah dengan modus properti syariah. PT Cahaya Mentari Pratama di Surabaya, Jawa Timur menawarkan perumahan syariah Multazam Islamic Residence, bahkan kasusnya turut menyeret Yusuf Mansyur. Terbaru, ada investasi Kampoeng Kurma yang menawarkan investasi kebun kurma dengan janji imbal hasil tinggi. ${ }^{2}$ Mulia Ardi, Diskursus Etika Bisnis Islam dalam Dinamika Bisnis Kontemporer, AN-NISBAH, Vol. 01, No. 02,
April 2015, hlm. 49

2 Kontan.co.id diakses pada 17 Maret 2020 
Selain itu, industri halal thayyib saat ini telah menjadi kebutuhan dunia berkembang semakin pesat. Situasi ini memerlukan kesiapan penuh dari seluruh pihak yang terlibat atau memiliki perhatian dan tanggung jawab dalam penyelenggaan produk halal thayyib. Indonesia adalah negara dengan jumlah penduduk muslim terbesar di dunia sehingga memiliki tanggung jawab besar untuk memelopori perkembangan industri halal thayyib dunia. Mulai tanggal 17 oktober 2019 pemerintah mewajibkan sertifikasi halal bagi produk yang beredar di Indonesia.

Berdasarkan realitas tersebut, sebagai agama yang paripurna dan sempurna, Islam mengandung ajaran yang sarat nilai fundamental yang menjadi landasan dalam berbisnis. Seluruh isi dan kandungan yang ada di dalam Al-Quran dan hadis harus bisa menjiwai etika bisnis dalam Islam. Nilai yang terkandung secara komprehensif dalam kedua sumber tersebut telah membangun etika bisnis bagi pelaku ekonomi dalam pandangan Islam. Dalam Islam, konsep bisnis itu bermuara pada bisnis yang halal dan thayyib. Lebih lanjut, para pelaku bisnis perilakunya juga harus mencerminkan nilai-nilai terkandung di dalam al-Qur'an dan hadis. Selain itu, orientasi bisnisnya juga harus mengutamakan kebaikan bagi manusia sebagai wujud pelaksanaan maqashid al-syariah (tujuan penerapan hukum syariah). ${ }^{3}$
Menurut Jasser Auda, salah satu pencetus maqashid al-syari'ah kontemporer berpendapat bahwa Maqasid al-syariah perlu memanfaatkan pendekatan sistem sebagai salah satu cara berpikir dan metode analisisnya. Pendekatan tersebut merupakan salah satu pendekatan baru dalam bidang kajian hukum Islam dan Ushul al-Fiqh yang belum pernah digunakan sebelumnya. Ada beberapa fitur sistem yang diterapkan oleh Jasser Auda dalam maqasyid syariah sebagai metode analisisnya, yaitu (1) dimensi kognisi dari pemikiran keagamaan (cognition), (2) menyeluruh (wholeness), (3) keterbukaan (openness), (4) hierarki berpikir yang saling mempengaruhi (interrelated hierarchy), (5) melibatkan berbagai dimensi dalam berpikir keagamaan (multidimensionality) dan (6) kebermaksudan (purposefullness). ${ }^{4}$

Lebih lanjut menurut Jasser Auda, Maqasid al-syariah harus ditempatkan sebagai prinsip dasar dan metodologi fundamental dalam mereformasi hukum Islam kontemporer yang dia gagas, karena efektivitas suatu sistem itu didasarkan pada tingkat pencapaian tujuan atau maqashid syariahnya. ${ }^{5}$

Dalam kaitannya dengan bisnis, etika bisnis Islam berupaya menjelaskan persoalan bisnis yang halal dan thayyib secara mendalam menurut pandangan hukum Islam yang tentunya harus memperhatikan maqasid al-syariahnya. Nilai-nilai Islam

3 Ardi, Op.cit, hlm. 49

4 Retna Gumanti, Maqasid Al-Syariah Menurut Jasser Auda (Pendekatan Sistem dalam Hukum Islam), Jurnal Al-Himayah Volume 2 Nomor 1 Maret 2018, hlm. 116

5 Ibid., hlm. 117 
yang berasal dari ayat al-Quran harus menjadi landasan bagi para pelaku bisnis sebagai sarana untuk mengantisipasi atau mencegah kecenderungan praktek bisnis yang negatif. Saat ini, logika bisnis menghendaki pragmatisme dalam berbisnis. Effeknya, moralitas terabaikan karena tidak menawarkan keuntungan yang nyata dan besar. Dalam hal ini, etika bisnis Islam diharapkan mampu membenahi kecenderungan bisnis yang hanya menonjolkan besarnya keuntungan semata (pragmatism) tanpa orientasi yang jelas. Lebih lanjut, etika bisnis Islam ingin membingkai dan mewujudkan praktik bisnis yang kondusif agar berdampak pada hasil yang positif, yaitu halal dan thayyib.

Bisnis yang halal adalah bisnis yang dalam implementasinya tidak bertentangan dengan syari'at Islam, misalnya bisnis yang mengandung unsur riba, penipuan, dan pencurian. Bisnis yang dilakukan dengan cara tersebut memberikan konsekuensi haram atau dosa bagi pelakunya. Bisnis yang halal pun juga belum tentu thayyib atau baik, karena ada beberapa etika yang harus diperhatikan dalam berbisnis seperti keseimbangan, tanggung jawab, kemanfaatan, dan lain-lain. Bisnis yang baik akan menempatkan manusia sebagai locus utama, subjek maupun objek bisnis. Jika tidak, maka tentu saja akan berdampak pada penempatan bisnis sebagai suatu kegiatan amoral.
Mengingat minimnya kajian etika bisnis halal thayyib, maka penting diadakan kajian tersebut dalam persepektif maqashid al-syari'ah kontemporer sehingga kajian etika bisnis tersebut bisa lebih konstektual dengan kondisi saat ini. Kajian yang sudah ada hanya menjelaskan etikabisnis Islam secaraumum. Di antaranya adalah: pertama, tulisan Darmawati tentang Etika bisnis dalam perspektif Islam: Eksplorasi Prinsip Etis al-Quran dan Sunnah yang menyimpulkan bahwa diperlukan suatu cara pandang baru dalam melakukan kajiankajian keilmuan tentang bisnis dan ekonomi yang lebih berpijak pada paradigma pendekatan normatif-etik sekaligus empirik induktif yang mengedepankan penggalian dan pengembangan nilai-nilai al-Qur'an, agar dapat mengatasi perubahan dan pergeseran zaman yang semakin cepat. ${ }^{6}$

Kedua, tulisan Ahmad Syukron tentang Membongkar Konsep Etika Bisnis dalam al-Quran: Perspektif Epistimologis yang menyimpulkan bahwa etika bisnis dalam Islam mempunyai derajat nilai yang tinggi sehingga patut dijadikan sebagai landasan dalam menjalankan bisnis. $^{7}$

Ketiga, tulisan Matnin tentang Konsepsi Etika Bisnis dalam al-Quran dan Sunnah yang menyimpulkan bahwa perlu suatu rekonstruksi kesadaran tentang bisnis, baik sebagai aktivitas yang dilakukan oleh perorangan maupun entitas bisnis yang dilakukan melalui

6 Darmawati, Etika bisnis dalam perspektif Islam: Eksplorasi Prinsip Etis al-Quran dan Sunnah, E-Journal STAIN Samarinda, diakses pada tanggal 15 Maret 2020

7 Ahmad Syukron tentang Membongkar Konsep Etika Bisnis dalam al-Quran:Perspektif Epistimologis, E Journal STAIN Pekalongan, diakses pada tanggal 15 Maret 2020 
organisasi atau perusahaan, yang kesemuanya bukanlah semata-mata bersifat duniawi. ${ }^{8}$

Dengan demikian, berdasarkan problem dan kajian di atas, maka penelitian ini menitikberatkan pada etika bisnis halal thayyib yang dianalisis menggunakan maqashid al-syariah kontemporer Jasser Auda.

\section{Metode Penelitian}

Penelitian ini termasuk penelitian normatif dengan pendekatan konseptual. Metode pengumpulan bahan hukum menggunakan dokumentasi dengan mengkaji referensi atau bahan hukum baik bahan hukum primer, sukender, mapun tersier yang sesuai dengan penelitian. Sedangkan pengolahan bahannya dilakukan dengan tiga tahapan, yaitu editing, claasifying, dan concluding. Analisis bahannya dengan deskriptif- kualitatif.

\section{Pembahasan}

\section{A. Konsep Bisnis Halal Thayyib dalam Islam}

Kata bisnis berasal dari bahasa inggris, yaitu Bussiness, yang dibentuk dari kata sifat busy yang artinya kesibukan, yang dapat diartikan sebagai aktivitas ekonomi, yakni kegiatan membuat (produksi), menjual (distribusi), membeli (konsumsi) barang dan jasa serta kegiatan penanaman modal (investasi). Sementara itu, ada pendapat lain yang mengungkapkan bahwa bisnis adalah usaha-usaha manusia yang meliputi produksi, pertanian, distribusi, konstruksi, komunikasi, transportasi, usaha barang dan jasa.

Sedangkan kata halal berasal dari hallayahillu yang berarti mengurai ikatan (hallul 'uqdah) atau berarti terlepas atau tidak terikat, al-Quran kemudian menggunakan kata ini untuk menunjukkan makanan yang halal. Dalam kaitan ini, M. Qurasih Shihab menjelaskan bahwa sesuatu yang halal pada hakikatnya terlepas dari ikatan bahaya duniawi dam ukhrawi sehingga kata ini dalam agama juga diartikan boleh.

Sementara kata thayyib berasal dari kata thaba-yathibu yang berarti sesuatu yang dirasakan nikmat oleh jiwa dan raga. Ada yang mengartikan sesuatu yang menenangkan jiwa ketika menikmatinya. Karenanya, tidak membahayakan dirinya baik jasmani maupun rohani. Lebih tegasnya, thayyib berarti baik, sehat dan menetramkan. ${ }^{9}$

Islam mengajarkan kepada manusia bahwa umat Islam hanya diperbolehkan mengkonsumsi dan memproduksi sesuatu (barang atau jasa) yang halal dan thayyib. Dalam hal ini, Islam sangat memperhatikan etika yang ada pada masyarakat yang berlaku secara umum seperti keadilan, kejujuran, keterbukaan, dan persaingan sehat. Nilai tersebut sangat penting dan diprioritaskan dalam bisnis Islam. Oleh karena itu, keterikatan seorang muslim dengan etika

8 Matnin, Konsepsi Etika Bisnis dalam al-Quran dan Sunnah,E Journal STAI Al-Khairat Pamekasan, diakses pada 15 Maret 2020

9 Kementerian Agama RI, Tafsir al-Quran Tematik: Pembangunan Ekonomi Umat,(Jakarta: Lajnah Pentashihan Mushaf al-Quran Badan Litbang dan Diklat Kementerian Agama RI, 2012), hlm. 196-197 
tersebut akan menjadi kontrol atau pedoman dalam berbisnis.

Secara umum, Islam memberikan beberapa pedoman dalam berbisnis yang halal dan thayyib, yaitu Islam tidak memperkenankan umatnya hanya bekerja untuk mencari uang semaunya dengan cara yang bertentangan dengan nilai Islam, seperti pemalsuan, kecurangan, penipuan, dan ketidakjelasan . Islam mengajarkan bahwa untuk mencari rizki harus halal sekaligus tidak melanggar hukum. Hal ini bisa dipahami dari firman Allah dalam Q.S. al-Baqarah ayat 168 yang artinya:

Artinya: Wahai manusia!Makanlah dari (makanan) yang halal dan baik yang terdapat di bumi.

Ayat tersebut memberikan pengertian bahwa setiap manusia diberi kesempatan yang seluas-luasnya untuk mengonsumsi apa saja yang telah diciptakan Allah di muka bumi ini asalkan halal. Oleh karena itu, seruan universal yang ditujukan kepada semua umat manusia bukanlah suatu paksaan, namun sesuatu yang wajar dan adil. Sebab manusia pada kenyataannya meskipun tidak menyembah Allah mereka selalu memperoleh rezekiNya selama hidup di dunia. Bahkan yang perlu disadari adalah bahwa mengonsumsi dan mencari rizki yang halal bukan untuk menyenangkan Allah, tetapi demi kemanfaatan dan kesehatan manusia itu sendiri, jiwa dan raga, sekaligus sebagai wujud pengabdian manusia kepadaNya. ${ }^{10}$
Dalam hal ini, Ibnu Asyur menjelaskan bahwa pada mulanya ayat tersebut ditujukan kepada orang-orang musyrik, karenanya perintah mengonsumsi makanan yang halal dimaksudkan untuk mencela, sebagaimana yang ditunjukkan pada redaksi setelahnya, yaitu janganlah mengikuti jejak syaithan. Oleh karena itu, perintah ini bagi umat Islam, bukan sekedar bersifat informative, namun sebagai penegasan agar senantiasa mencari apa aja yang halal. Dengan demikian, kata halal mengacu pada cara dan jenisnya, sedangkan kata thayyib terkait dengan alasannya, yakni demi kesehatan jasmani dan rohani. ${ }^{11}$

Lebih lanjut, Islam hanya membolehkan bisnis yang berorientasi pada kemaslahatan umum. Ada beberapa prinsip yang harus menjadi landasan atau pedoman dalam menjalankan bisnis, yaitu: seperti saling ridha atau suka sama suka sehingga menyebabkan munculnya kezaliman dalam transaksi. Pedoman ini bersifat kulli (menyeluruh) yang berarti bahwa bisnis yang tidak mendatangkan kemaslahatan atau kemanfaatan itu tidak dibenarkan. Sebaliknya, bisnis yang mendatangkan manfaat di antara umat manusia dengan dasar saling ridha atau suka sama suka dan adil itu dibenarkan. ${ }^{12}$ (Khoiruddin, 2015) Hal ini sebagaimana dijelaskan oleh Allah dalam firman-Nya surat al-Nisa' ayat 29-30 yang artinya:

Artinya: Hai orang-orang yang beriman! Jangan kamu memakan 
harta-harta saudaramu dengan cara yang batil, kecuali harta itu diperoleh dengan jalan dagang yang ada saling kerelaan dari antara kamu. Dan jangan kamu membunuh diri-diri kamu, karena sesungguhnya Allah Maha Pengasih kepadamu. Dan barangsiapa berbuat demikian dengan sikap permusuhan dan penganiayaan, maka kelak akan Kami masukkan dia ke dalam api neraka.

Penyebutan kata makan dalam ayat tersebut mengindikasikan bahwa makan merupakan tujuan utama dari segala kegiatan yang terkait dengan harta dan uang. Kata makan di sini juga sebagai metofora dari setiap usaha pengambilan manfaat atas sesuatu secara sempurna. Dengan demikan, kata makan dalam ayat ini secara umum berkonotasi negatif. Sementara kata batil adalah segala bentuk praktek yang tidak halal atau mengandung unsure penipuan. Kata ini juga mengarah pada keharaman yang sudah pasti, bukan dugaan atau yang masih diperdebatkan status hukumnya.

Sedangkan kata jalan dagang yang ada saling kerelaan bukan berarti melegalkan transaksi yang illegal atau haram. Oleh karena itu, bentuk transaksi apapun, baik yang keuntungannya kecil maupun besar, layak disandangkan dengan kata batil di dalamnya, jika memang bentuk transaksinya dilakukan dengan cara batil. Meskipun demikian, jika dikembalikan secara terminologis, maka kata tijarah atau perdagangan tidak masuk dalam kategori memakan harta dengan cara batil, meskipun dalam prakteknya si penjual mengambil keuntungan dari pembeli. Hal ini dikarenakan mengambil keuntungan yang wajar demi memenuhi kebutuhan adalah tujuan dari segala bentuk perdagangan dan bukan dianggap mengambil hak orang lain. Akan tetapi, mengambil keuntungan yang terlalu besar akan menghilangkan keberkahan. ${ }^{13}$

Dengan demikian, ayat di atas memberikan pengertian bahwa bisnis yang diperbolehkan dalam Islam harus memenuhi syarat, yaitu: bisnis itu harus didasari atau dilandasi dengan kerelaan di antara kedua belah pihak. Dengan kata lain, ayat ini menegaskan bahwa seseorang dilarang menzalimi atau merugikan orang lain hanya untuk kepentingan diri sendiri (vested interest).

Jika hal tersebut dipegang oleh pelaku bisnis, maka bisnis yang halal dan thayyib itu akan mudah terwujud sehingga akan diperoleh keberkahan usaha baik di dunia maupun di akhirat. Keuntungan di dunia dapat berupa hubungan yang baik dan menyenangkan, sedangkan keuntungan akhirat berupa nilai ibadah karena bisnis dilakukan dengan jujur. ${ }^{14}$

\section{B. Maqashid Syari'ah Kontemporer Jasser Auda}

Secara bahasa, kata maqashid diambil dari bahasa Arab maqashid yang merupakan bentuk jama' dari kata maqsud yang berarti maksud, tujuan, prinsip, sasaran, dan niat. Dengan kata lain, maqashid hukum Islam adalah maksud, 
tujuan atau sasaran dibalik hukum. ${ }^{15}$ Menurut ulama' atau teoretikus hukum Islam, Maqashid juga merupakan ungkapan untuk mashalih atau kemaslahatan-kemaslahatan, seperti yang diungkapkan oleh 'Abd al-Malik al-Juwaini (w. $478 \mathrm{H} / 1185 \mathrm{M}$ ), salah satu kontributor awal terhadap teori maqashid, yang menggunakan istilah maqashid dengan mashalih 'ammah (kemaslahatan-kamaslahatan umum) secara bergantian.

Lebih lanjut, Maqashid syariah adalah prinsip yang memberikan atau menyediakan jawaban atas pertanyaan seputar hukum Islam yang mengandung hikmah dibalik hukum tersebut. ${ }^{16}$ Maqashid ini juga merupakan tujuan yang hendak dicapai oleh hukum Islam dengan mengutamakan kemaslahatan. Selain itu, Maqashid juga dimaknai sebagai tujuan atau maksud ilahiyah dan konsep-konsep moral yang menjadi landasan atau pedoman hukum Islam.

Teori maqashid terus berkembang dari abad ke abad terutama di abad ke 20M. Para teoretikus kontemporer mengkritik klasifikasi keniscayaan model tradisional dengan beberapa alasan, yaitu:

1. Jangkauan maqashid tradisional itu mencakup seluruh hukum Islam. Akan tetapi tidak memasukkan maksud khusus dari suatu atau sekelompok nas/hukum yang meliputi topik fiqih tertentu.

2. Maqashid tradisional cenderung lebih mengutamakan individu jika dibandingkan dengan keluarga, masyarakat, dan umat manusia.

3. Dalam klasifikasi maqashid tradisional tidak memasukkan nilai dasar yang umum seperti keadilan dan kebebasan.

4. Maqashid tradisional dideduksi dari kajian literature fiqih, ketimbang sumbersumber syariat (al-Quran dan hadis).

Untuk itu, para cendikiawan muslim modern dan kontemporer, seperti Jaseer Auda, memperkenalkan konsep dan klasifikasi maqashid yang baru dengan memasukkan dimensi-dimensi maqashid yang baru, guna memperbaiki kekurangan pada konsep maqashid tradisional. Dalam hal ini, Jasser Auda membagi maqashid menjadi 3 tingkatan, yaitu:

1. Maqashid umum yang dapat dikaji pada seluruh aspek hukum Islam, seperti keniscayaan dan kebutuhan hajiyyat ditambah dengan keadilan dan kemudahan.

2. Maqashid khusus yang dapat diamati pada seluruh isi bab hukum Islam, seperti perlindungan dari criminal, monopoli dalam hukum ekonomi, dan kesejahteraan anak dalam hukum keluarga.

3. Maqashid parsial, yaitu maksud atau tujuan dibalik suatu nash, seperti tujuan mengungkapkan kebenaran, maksud meringankan kesulitan, maksud member makan orang miskin, dan lain-lain.

15 Muhaamad Lutfi Hakim, Pergeseran Pradigma Maqashid Syariah dari Klasik sampai Kontemporer, Manahij, VolX No 1 Juni 2016, hlm. 3

16 Ghafar Shidiq, Teori Maqashid Syariah dalam Hukum Islam, Sultan Agung Vol. XLIV No. 118 Juni-Agustus 2009, hlm. 118 
Selain itu, jangkauan maqashid kontemporer juga lebih luas, yaitu kalangan masyarakat, bangsa, bahkan seluruh umat manusia. Oleh karena itu, menurut Jasser Auda, maqashid merupakan salah satu media intelektual dan metodologi masa kini yang terpenting untuk reformasi Islami. Itu merupakan metodologi dari “dalam” keilmuan Islam yang menunjukkan nalar dan agenda Islam.

Sebenarnya, pemikiran Maqasid al Syari'ah Jasser Auda berawal dari kegalauannya terhadap ilmu Usul al-Fiqh tradisional, yaitu:

1. Usul al-Fiqh tradisional lebih cenderung tekstual dan tidak berorientasi pada tujuan teks. Hal ini dipengaruhi karena para ulama' lebih fokus pada usul al-Fiqh dalam aspek bahasa. Terkait dengan persoalan ini, menurut Jamal al-Bana, para ulama'usul al-Fiqh lebih fokus pada aspek bahasa dari pada ahli bahasa itu sendiri. Walaupun kajian terkait bahasaitu penting, namun menjadikannya landasan satu-satunya dalam merumuskan hukum itu bisa menjadi masalah, karena pendekatan bahasa sering mengabaikan tujan inti dan syariah.

2. Klasifikasi yang yang ada pada teori usul al-Figh itu lebih mengacu kepada logika biner dan dikotomis. Misalnya, terkait dengan pembagian 'am dan khas, qath'i dan dhanni, mutlaq dan muqayyad dan lain-lain. Menurut ulama' tradisional, pembagian tersebut harus diperhatikan dalam istinbath hukum, terutama jika ada dalil yang kontradiktif. Jika ada dalil yang kontradiktif, maka dalil yang qat'i harus didahulukan dari yang dhanni, atau dalil yang khas harus didahulukan dari dalil yang 'am atau dalil yang muqayyad harus didahulukan dari dalil yang mutlaq.

Dengan memperhatikan beberapa kelemahan tersebut, akhirnya Jasser Auda melakukan beberapa reformasi, yaitu:

1. Mereformasi Maqasid al-Syariah dalam perspektif kontemporer, yaitu dulu Maqasid al-Syariah lebih berorientasi pada penjagaan dan pelestarian dan saat ini Maqasid al-Syariah lebih berorientasi atau mengarah pada pengembangan dan pemuliaan Human Rights (Hakhak Asasi). Dalam hal ini, Jasser Auda mengusulkan agar pengembangan SDM menjadi topik utama dalam kemaslahatan masyarakat saat ini. Dampaknya, hubungan Maqasid al-Syariah akan lebih dapat diukur secara empiris.

2. Menawarkan hak asasi manusia (HAM) sebagai dasar atau pedoman dalam menyusun tipologi teori hukum Islam kontemporer. Dalam hal ini, Jasser Auda mengusulkan adanya tipologi baru dalam teori hukum Islam sebagai bentuk pendekatan dalam mereformasi hukum Islam kontemporer. Lebih lanjut, menurutnya,terdapattigakencenderungan atau aliran dalam hukum Islam, yaitu: Tradisionalisme, Modernisme, dan Posmodernisme. Ketiga aliran tersebut 
merupakan kecenderungan, bukan mazhab. Dampaknya adalah tidak ada lagi batasan dalam mazhab Sunni, Muktazilah, Syiah, Khawarij, dan lainlain. Dengan demikian, seharusnya seorang faqih harus lebih fleksibel dalam menyikapi suatu kasus perbedaan dalam Fikih. Hal tersebut dapat berpindah atau berubah kecenderungan sesuai dengan pendekatan yang digunakan.

3. Mengusulkan pendekatan sistem dalam hukum Islam yang berbasis Maqasid al-Syariah. Bidang inilah yang menjadi kontribusi signifikan Jasser Auda dalam mereformasi filsafat hukum Islam melalui fungsi beberapa fitur sistem. ${ }^{17}$

\section{Formulasi Bisnis Halal Thayyib dalam Perspektif Maqashid Syari'ah KontemporerJasser Auda}

Penerapan maqashid syari'ah dalam bisnis halal thayyib merupakan penjabaran dari salah satu maqashid syariah, yaitu untuk menjaga dan memenuhi hajat dan maslahat akan harta (hifdzul mal). Konsep tersebut bisa ditinjau dari segi bagaimana mendapatkannya atau dari segi memelihara harta yang sudah dimiliki. Hifdzul mal juga merupakan rumpun kaidah dalam bidang muamalah yang mencakup maqashid 'ammah dan maqashid khassah.Maashid 'ammah merupakan tujuan disyariatkan beberapa kumpulan hukum atau lintas hukum. Sedangkan maqashid khassah atau biasa disebut dengan maqashid juziyyah merupakan tujuan disyariatkan satu hukum tertentu yang merupakan hasil istiqra'(kajian) para ulama' terhadap nash dan hukum-hukum syari'ah yang menghasilkan kepastian (qath 'i) bahwa syari'at ini telah menetapkannya sebagai tujuan yang memberikan akibat dan implikasi. ${ }^{18}$

Dalam hal ini, ada beberapa prinsip umum yang harus menjadi pedoman, yaitu:

\section{a. Tidak bersifat illegal.}

Segala bentuk praktek illegal dalam bidang apapun dihukumi haram. Secara terminologis, praktek illegal bisa kategorikan sebagi sesuatu yang batil, sebagai lawan dari yang haq, bukan sebagai lawan dari sahih. Artinya, praktek yang menyimpang tersebut sudah diketahui secara pasti dan meyakinkan menurut Islam sebagai praktek yang haram. Hal ini sesuai dengan Q.S. al-Nisa' ayat 29.
Artinya: Hai orang-orang yang beriman, janganlah kamu saling memakan harta sesamamu dengan jalan yang batil, kecuali dengan jalan perniagaan yang berlaku dengan suka sama-suka di antara kamu.

Dari ayat tersebut dapat dipahami bahwa Allah melarang orang mukmin melakukan transaksi yang dilarang oleh Allah (dengan cara batil). Hendaklah transaksi tersebut dilandasi dengan kerelaan. ${ }^{19}$ Larangan ini

17 Retna Gumanti, Maqasid Al-Syariah Menurut Jasser Auda (Pendekatan Sistem dalam Hukum Islam), Jurnal Al-Himayah Volume 2 Nomor 1 Maret 2018, hlm. 117

18 Nurhadi, Maqashid Ammah dan Khashah Operasional Bank Syariah, Jurnal Ekonomi Islam Volume 9, Nomor 2, November 2018, hlm. 152-168

19 Irfan B. Nurdin, Sistem Ekonomi Islam Berlandaskan Etika Bisnis, jurnal AD-DEENAR Jurnal Ekonomi dan Bisnis, hlm. 1 
mempunyai maqashid bahwa transaksi bisnis itu tidak boleh menimbulkan kebatilan atau kecurangan, karena ini bertentangan dengan prinsip maqashid yang orientasinya pada kemaslahatan.

b. Prinsip Pemerataan dan Berbasis Masyarakat.

Prinsip ini bisa dipahami dari firman Allah dalam Q.S. al-Hasyr ayat 7 yang artinya:

Artinya: Agar harta itu jangan hanya beredar di antara orang-orang kaya saja di antara kamu

Ayat tersebut menunjukkan bahwa tujuan syariat yang terkait dengan harta adalah agar harta tersebut tidak hanya dinikmati oleh kalangan tertentu atau kalangan elit dan kaya saja. Oleh karena itu, di dalam ayat tersebut disebut kelompok tertentu, seperti anak yatim, fakir, miskin, dan ibnu sabil. Ini menunjukkan bahwa di dalam struktur masyarakat manapun kelompok ini pasti ada dan tidak jarang sebagai kelompok mayoritas. Atas dasar inilah, maka dalam kegiatan bisnis harus memperhatikan keberadaan mereka. Hasil bisnis yang sudah mencapai nisabnya harus dikeluarkan zakatnya kepada mereka yang berhak (termasuk kelompok tersebut). Prinsip ini sesuai dengan maqashid khassah, bahwa tujuan transaksi bisnis itu adalah untuk kemakmuran masyarakat, bukan hanya individu, sehingga kesejahteraan itu harus merata agar tidak ada kesenjangan sosial di masyarakat. c. Prinsip Kemakmuran yang berkeadilan

Adil dalam al-Quran diungkapkan dengan dua term, yaitu al-adl dan al-qist. Kata al-adl lebih umum dari pada kata al-qist. Kata al-qist pada mulanya merupakan proses arabisasi untuk menunjukkan arti adil dalam masalah putusan dan hukum. Sementara kata al-adl menyangkut banyak hal. Karakter term al-adl secara jelas bisa dilihat ayat-ayat selain masalah hukum. Seperti surat al-Nisa' ayat 3 dan 129 tentang poligami, surat al-Baqarah ayat 282 tentang utang-piutang, surat al-Hujurat ayat 9 tentang penyelesaian konflik, dan lain-lain. Rasulullah diutus Allah untuk membangun keadilan. Kecelakaan besar apabila seseorang berbuat curang, yaitu apabila menerima suatu takaran atau timbangan dari orang lain meminta untuk dipenuhi semuanya. Sementara itu, apabila menakar atau menimbang untuk orang lain selalu dikurangi. ${ }^{20}$ Hal ini menunjukkan bahwa umat Islam diperintahkan untuk senantiasa berlaku adil dalam segala hal dan tidak boleh dipengaruhi oleh rasa kebencian terhadap pihak-pihak yang melakukan transaksi dengannya.

Dalam kaitannya dengan bisnis, maka keadilan yang dibangun oleh Islam adalah keadilan yang berbasis pada kesejahteraan sosial yang mengedepankan terciptanya keadilan sosial dari pada privatisasi dalam berbisnis sehingga terwujudlah kemakmuran masyarakat. ${ }^{21}$ Prinsip ini sesuai dengan

20 Nur Dinah Fauziyah, MUawanah, dan Sundari, Etika Bisnis Syariah,(Literasi Nusantara, Malang: 2019

21 Kemenag RI, Tafsir al-Quran..., hlm. 192 
maqashid 'ammah di mana, orientasi dari transaksi bisnis adalah salah satunya terwujudnya keadilan bagi masyarakat, bukan hanya individu.

\section{d. Prinsip tidak saling Mendzalimi}

Secara fitrah, setiap manusia ingin selalu mendapatkan keuntungan dalam menjalankan usahanya, sebagaimana dia juga tidak mau dirugikan. Oleh karena itu, seharusnya setiap manusia juga tidak boleh merugikan pihak lain atas nama apapun. Di sinilah Islam meletakkan prinsip-prinsip muamalah agar tidak ada yang dirugikan atau merugikan, sebagaimana firman Allah Swt dalam surat al-Baqarah ayat 279:

Artinya: Kamu tidak berbuat Dzalim (merugikan) dan tidak didzalimi (dirugikan)

Larangan untuk saling mendzalimi dalam kegiatan perekonomian bukan saja menyangkut hukum praktis namun juga terkait dengan kelangsungan hidup sebuah bangsa atau masyarakat. Kedzaliman dalam bidang ekonomi atau kejahatan ekonomi adalah segala bentuk transaksi yang mengandung unsure ghurur (penipuan), maisir (spekulatif dan manipulative), dan riba. ${ }^{22}$ Larangan tersebut mengandung maqashid bahwa transaksi bisnis dimaksudkan untuk mewujudkan kemaslahatan, bukan penipuan atau kerusakan.

e. Prinsip Kejelasan.

Dalam setiap transaksi bisnis, harus ada kejelasan yang diketahui oleh kedua belah pihak. Sukap tidak adanya transparansi dalam segi kualitas akan menghilangkan sumber dimensi keberkehan dalam berbisnis. Segala bentuk tindakan yang menimbulkan kerugian pihak lain dikarenakan tidak adanya kejelasan kualitias barang mengakibatkan terjadinya eksploitasi hak-hak yang tidak dibenarkan dalam ajaran Islam. ${ }^{23}$

Untuk itu, Islam memberlakukan ketentuan tautsiq dalam akad atau transaksi muamalah maliyah, seperti ketentuan bahwa setiap transaksi harus tercatat, disaksikan, dan boleh bergaransi. Dalam hal ini Ibnu Asyur berpendapat bahwa menjaga kepercayaan muktasib (orang yang bekerja) itu dengan melindungi hartanya, sebagaimana firman Allah dalam surat al-Nisa' ayat 29:

Artinya: hai orang-orang yang beriman, janganlah kamu saling memakan harta sesamamu dengan jalan yang batil, kecuali dengan jalan perniagaan yang berlaku dengan suka sama suka di antara kamu. (Q.S. al-Nisa': 29)

Ayat tersebut menjadi legalitas atau dasar dari salah satu maqashid syariah, yaitu hifdzul mal yang harus diterapkan dalam setiap transaksi bisnis. Hifdzul mal tersebut diimplementasikan agar ada kerelaan dari kedua belah pihak dalam setiap transaksi. Maqashid tersebut juga sesuai dengan prinsip dalam perdagangan yang harus dilakukan atas dasar suka sama suka (rela). Prinsip tersebut berimplikasi sangat luas, karena melibatkan lebih dari satu pihak, sehingga kegiatan jual 
beli harus dilakukan secara sukarela, tanpa paksaan. Perdagangan tidak boleh dilakukan dengan memanfaatkan ketergantungan karena tidak ada pilihan. ${ }^{24}$

Selain itu, penting juga adanya pemahaman yang sama tentang apa yang diperdagangkan. Informasinya harus jelas, terbuka, dan dapat dipahami oleh kedua belah pihak (penjual dan pembeli. Oleh karena itu, standarisasi dan labelisasi menjadi hal yang penting dan menentukan.

\section{f. Prinsip Pemenuhan Transaksi}

Setiap transaksi bisnis yang sudah disepakati dari kedua belah pihak harus dipenuhi, sebagaimana dijelaskan dalam al-Quran surat al-Maidah ayat 1:

Artinya: Hai orang-orang yang beriman, penuhilah akad-akad itu.. (Q.S. al-Maidah: 1)

Dari ayat tersebut dapat dipahami bahwa setiap akad atau transaski, termasuk bisnis, yang sudah disepakati wajib ditunaikan. Jika mereka melanggar atau tidak memenuhi transaksi tersebut, maka akan mendatangkan banyak kemadaratan, seperti timbulnya permusuhan, kerugian, atau penipuan. Itu jelas melanggar maqashid syariah yang dimaksudkan untuk memenuhi kemaslahatan umat. Dengan kata lain, pemenuhan transaksi yang sudah disepakati tersebut dimaksudkan untuk menghindari mafsadah yang timbulkan dari tidak terpenuhi transaksi yang sudah disepakati. Oleh karena itu, komitmen kedua belah pihak yang bertransaksi menjadi hal penting dan menentukan keberlanjutan transakasi tersebut demi menghindari mafsadah.

g. Prinsip Keseimbangan dan Kesederhanaan.

Mengonsumsi secara berlebihan berarti memberikan kontribusi bagi setiap berjalannya system ekonomi pertumbuhan yang boros energi dan rakus sumber daya alam. Selain itu juga mengonsumsi secara berlebihan itu juga semakin memperuncing kesenjangan sosial antara orang yang miskin dan kaya. Oleh karena itu, prinsip keseimbangan dan kesederhanaan harus dipegang dalam melakukan bisnis atau kegiatan perekomian. ${ }^{25}$

Lebih lanjut, jika beberapa prinsip bisnis halal thayyib tersebut dikaji menurut perspektif maqashid syariah kontemporer Jasser Auda, maka ada beberapa maqashid dalam transaksi bisnis tersebut yang meliputi 3 tingkatan, yaitu:

\section{a. Maqashid 'Ammah.}

Dalam hal ini, transaksi bisnis harus mengedepankan keadilan. Dalam bisnis, prinsip adil merupakan suatu kewajiban bagi pelaku bisnis atau akad untuk menunaikan hak dan kewajibannya, misalnya menginvestasikan sesuatu dengan cara halal dan menunaikan kewajiban hak hartanya. Terkait dengan persoalan tersebut, Ibnu Asyur menyatakan bahwa prinsip adil dalam bisnis itu adalah bagaimana dalam berbisnis atau

24 Oni Sahroni, Adiwarman A. Karim, Maqashid Bisnis dan Keuangan Islam: Sintesis Fiqih dan Ekonomi,(Depok, Rajawali Pers: 2017), hlm. 66-67

25 Ibid.,hlm. 195 
untuk mendapatkan harta itu harus dilakukan dengan cara yang tidak menzalimi orang lain. Oleh karena itu, dalam setiap transaksi harus memperhatikan prinsip keadilan bagi kedua belah pihak yang bertransaksi. Hal ini dikarenakan, meskipun transaksi bisnis itu dilakukan atas dasar kerelaan, namun terkadang tidak mampu memenuhi aspek keadilan kepada pihak yang bertransaksi. Hal ini juga didukung oleh risetnya Matthew Rabin yang menjelaskan bahwa dalam setiap transaksi ada dua kesepakatan yang harus dipenuhi, yaitu kesepatan pasat dan kesepakatan rasa keadilan. ${ }^{26}$

Jika transaksi bisnis tidak dilandasi dengan prinsip keadilan, maka akan berdampak pada kerugian, penipuan, atau kezaliman. Inilah yang menjadi maqashid bisnis yang halal thayyib, yaitu menghindari adanya kerugiaan, kecurangan, penipuan, mafsadah atau kezaliman yang diakibatkan dari tidak adanya unsur keadilan dalam transaksi bisnis. Hal ini jelas bertentangan dengan maqashid syariah yang mempunyai orientasi pada kemaslahatan, bukan mafsadah.

\section{b. Maqashid Khassah}

Jika dilihat dari perspektif maqashid khusus, transaksi bisnis yang dilakukan harus mengedepankan kesejahteraan masyarakat, bangsa, bahkan umat manusia. Oleh karena itu, Islam sangat melarang praktek monopoli yang tujuannya untuk menjadikan barang dagangan atau produk dari bisnis itu langka sehingga harganya menjadi melambung tinggi. Dengan mereka akan mendapatkan keuntungan yang sangat banyak. Sementara masyarakat akan banyak dirugikan dengan praktek monopoli tersebut. Oleh karena itu, maqashid khusus transaksi bisnis adalah bukan hanya terciptanya kesejahteraan individu tetapi juga kesejahteraan masyarakat.

\section{c. Maqashid Parsial}

Jika dilihat dari perspektif maqashid Parsial, dibalik setiap transaksi bisnis yang halal thayyib pasti mempunyai maksud tertentu yang orientasinya adalah terwujudnya kemaslahatan, bukan mafsadah. Transaksi bisnis yang menyebabkan kerusakan atau kemadaratan jelas bertentangan dengan maqashid parsial.

\section{Etika Bisnis Halal Thayyib dalam Perspektif Maqashid Syariah Kontemporer Jasser Auda}

1. Maqashid larangan adanya unsur riba Artinya: Keadaan mereka yang demikian itu adalah disebabkan mereka berkata (berpendapat), sesungguhnya jual beli itu sama dengan riba, padahal Allah menghalalkan jual beli dan menghalalkan riba (Q.S. Al-Baqarah: 275)

Menurut mayoritas ulama', maksud riba dalam ayat di atas adalah riba dalam jual beli. Pendapat ini juga diungkapkan oleh Aisyah, Abi Sa'id al-Khudri, dan lain-lain. Sedangkan Ibnu Abbas, Ibnu Umar dan Muawiyah berpendapat bahwa maksud riba dalam ayat di atas adalah riba menurut arti bahasa yaitu 
riba jahiliyah (riba qardh). ${ }^{27}$ Dalam hal ini, itu indikator dari kecukupan sedangkan Ibnu 'Asyur merajihkan (mengunggulkan) peminjam itu indikator dari kefakiran. pendapat yang mengatakan bahwa maksud Oleh karena itu, Allah mengharamkan riba riba dalam ayat di atas adalah riba jahiliyah karena mengeksploitasi hajat orang fakir dan dengan dalil sebagai berikut:

a. Yang dimaksud riba dalam surat al-Baqarah ayat 275 di atas adalah riba jahiliyah, sedangkan riba jual beli dijelaskan dalam dalil-dalil lainnya

b. Hadis Rasulullah yang diriwayatkan oleh Usamah yang artinya: sesungguhnya riba terjadi pada riba nasi'ah. (hadis shahih Muslim, kitab buyu', bab bai' tho'am mitslan bi mitslin 5/50).

c. Hadis Aisyahyang artinya: Aisyah berkata ketika ayat-ayat riba di akhir surat al-Baqarah itu turun, maka dibacakan olehRasulullahSaw, kemudian Rasulullah Saw. mengharamkan berbisnis khamr. Masa rasulullah itu dekat dengan masa jahiliyah dan kebiasaanyya, termasuk riba jahiliyah dank arena dikhawatirkan beberapa praktek jual beli menjadi riba jahiliyah, maka beberapa bentuk jual beli tersebut diharamkan.

Dengan demikian, dalam surat al-Baqarah ayat 275 tersebut Allah membedakan antara jual beli dengan riba. Perbedaannya adalah antara kondisi pembeli dan peminjam, karena kebutuhan peminjam untuk menutupi hajat dirinya dan keluarganya. Sedangkan pembeli melakukan transaksi jual beli karena adanya kelebihan harta. Dengan kata lain, pembeli sebaliknya dengan menghalalkan jual beli dalam rangka membantu orang lain yang membutuhkan.

Riba Qardh (riba jahiliyah/riba nasi'ah) adalah riba yang ada atau muncul pada transaksi piutang yang tidak memenuhi kriteria untung yang muncul bersama biaya resiko dan hasil usaha yang muncul bersama biaya. Transaksi semacam ini mengandung pertukaran kewajiban menanggung beban, hanya karena berjalannya waktu. Praktek riba tersebut diharamkan menurut al-Quran. Oleh karean itu, semua ulama' sepakat bahwa riba tersebut hukumnya haram. ${ }^{28}$

Maqashid dari larangan riba tersebut adalah: Pertama, Untuk menghindari terjadi praktek kezaliman terhadap pelaku bisnis. Dalam berbisnis selalu ada kemungkinan adanya untung atau rugi. Memastikan sesuatu yang ada di luar kewenangan manusia merupakan salah satu bentuk kezaliman. Padahal dalam realitasnya, ternyata justru di situlah yang muncul dalam riba nasi'ah, yaitu terjadinya atau munculnya perubahan sesuatu yang tidak pasti menjadi sesuatu yang pasti. Hal tersebut dapat menimbulkan kezaliman terhadap salah satu dari kedua belah pihak, kedua belah pihak, atau pihak-pihak lain. Dengan demikian, hukumnya haram bagi pemberlakuan bunga untuk suatu pinjaman.

27 Sahroni, Op.cit, hlm. 84-87

28 Ibid., hlm. 88-90 
Kedua, riba jahiliyah dilarang karena melanggar suatu kaidah, yaitu setiap pinjaman yang memberikan manfaat kepada kreditor itu termasuk riba. Memberi pinjaman adalah transaksi kebaikan, sedangkan meminta kompensasi adalah transaksi bisnis. Jadi, transaksi yang awalnya diniatkan untuk transaksi kebaikan maka dilarang untuk diubah menjadi transaksi bermotif bisnis.

Ketiga, mencegah perbuatan dzalim yang dilakukan oleh para rentenir kepada kreditur atau penerima pinjaman. Hal ini dikarenakan bahwa praktek riba itu berarti pemberi pinjaman itu mengeksploitasi kreditur dengan memberlakukan bunga pada pinjaman yang diberikan.

Sedangkan riba buyu' atau disebut dengan riba fadhl adalah riba yang muncul diakibatkan karena ada pertukaran barang sejenis tetapi berbeda kuantitas, kualitas atau penyerahannya. Keaharaman riba buyu' ini memiliki tujuan atau maqashid, yaitu pertama, mencegah atau menghindari gharar dalam transaksi jual beli. Hal ini dikarenakan dalam jual beli atau pertukaran semacam ini mengandung ketidakjelasan yang dapat menimbulkan kedzaliman bagi kedua belah pihak. Selanjutnya juga bisa menimbulkan konflik dan permusuhan. Kedua, agar tidak menjadikan uang sebagai komoditas yang diperjualbelikan sehingga uang melahirkan uang dan tidak melahirkan barang. Seharusnya uang tersebut menjadi alat ukur dalam sirkulasi barang dan jasa.
Tujuan atau Maqashid di atas sejalan dengan pandangan ekonomi. Hal ini dkarenakan riba dapat dianggap sebagai transaksi yang menimbulkan eksploitasi karena mengambil keuntungan besar dengan tidak wajar. Dalam hal ini, riba juga dapat dipahami sebagai suatu transaksi yang mengandung information asymmetry atau kondisi lain yang berdampak pada proses tawar menawar yang tidak berimbang, sehingga salah satu dari kedua belah pihak ada pada kondisi terpaksa atau tak berdaya dan menerima seuatu ketetapan apapun yang dari pihak lain yang bertransaksi. ${ }^{29}$

2. Maqashid larangan adanya unsur gharar Gharar adalah sifat muamalah yang yang dapat mengakibatkan sebagian rukunnya tidak pasti (mastur al-aqibah). Lebih lanjut, gharar dapat dimaknai bahwa kedua belah pihak yang ada dalam transaksi itu tidak mempunyai kepastian atas suatu barang yang merupakan obyek transaksi baik berkaitaan dengan kauntitas, kualitas, harga, dan waktu penyerahan barang sehingga menyebababkan pihak kedua itu dirugikan. ${ }^{30}$ Ghrarar juga dapat terjadi jika mengubah sesuatu yang sudah pasti menjadi tidak pasti yang mencakup beberap hal, di antaranya adalah:

a. Gharar dalam kualita, misalnya transaksi jual beli anak sapi yang masih dalam kandungan induknya.

b. Ghrarar dalam kuantitas, misalnya jual beli ijo. 
c. Gharar dalam harga, misalnya murabahah selama 1 tahun dengan margin $20 \%$ atau murabahah 2 tahun dengan margin $40 \%$.

d. Gharar dalam waktu penyerahan, seperti transaksi jual beli pada barang yang hilang. ${ }^{31}$

Praktek ghurar tersebut jelas dilarang oleh Islam. Dengan demikian, seseorang yang melakukan transaksi atau memberikan syarat dalam akad yang mengandung unsur gharar, maka hukumnya haram, sebagaimana sabda Rasulullah Saw:

$$
\text { نهى رسوةل الله صلى الله عليه و سلم عن بيع الغرار }
$$

Artinya: Rasulullah Saw. melarang jual beli yang mengandung gharar.

Berdasarkan hadis tersebut, Imam Nawawi mengungkapkan bahwa hadis tersebut merupakan prinsip penting yang harus dipegang dalam transaksi muamalah (bisnis) yang mengatur masalah-masalah yang tidak terbatas.

Larangan gharar tersebut memepunyai maqshud atau tujuan sebagaimana dijelaskan dalam substansi gharar tersebut, bahwa bentuk transaksi apapun yang mengandung unsur gharar dapat menimbulkan kemadaratan, kerugian atau kezaliman bagi pihak-pihak yang bertransaksi atau lainnya. Hal ini dikarenakan banyaknya ketidak pastian dalam akad yang mengandung unsur gharartersebut. Sementara di dalam Islam sudah diatur bahwa setiap transaksi harus didasarkan pada prinsip kerelaan, keadilan dari kedua belah pihak dan kejelasan barang atau transaksi. Dengan kata lain, maqshud dari larangan gharar adalah untuk mengihindari kemudaratan, kerugiaan, ketidak adilan dan kezaliman dalam transaksi bisnis. Dampak dari transaksi yang mengandung gharar salah satunya adalah salah satu pihak yang merasa dirugikan atau dicurangi maka volume perdagangan ataupun transaksi akan berkurang.

Maqshud tersebut sesuai dengan pendapat dan hasil riset dari para pakar ekonomi, misalnya hasil risetnya Matthew Rabin yang berjudul "Incorporating Fairness into game Theory ang Economics" yang menyatakan bahwa dalam setiap transaksi ada dua kesepakatan yang harus terpenuhi , yaitu kesepakatan pasar (market equilibria) dan kesepakatan rasa keadilan (fairness equilibria). ${ }^{32}$

\section{Maqashid larangan maisir}

Maisir adalah suatu permainan yang memposisikan salah satu dari kedua belah pihak harus menanggung beban pihak lain yang diakibatkan dari permainan tersebut. dalam hal ini, setiap permainan yang ada, baik yang berbentuk game of chance, game of skill ataupun natural events, harus menghindari munculnya zero sum game, yaitu suatu kondisi yang memposisikan salah satu atau beberapa pemain harus menanggung beban pemain lain. Dalam Islam, praktek tersebut jelas dilarang atau haram, sebagaimana dijelaskan di dalam al-Quran surat al-Maidah ayat 90: 
Artinya: Hai orang-orang yang beriman, sesungguhnya (meminum) khamr, berjudi, (berqurban) untuk berhala, mengundi nasib dengan panah, adalah termasuk perbuatan syaithan. Maka jauhilah perbuatanperbuatan itu agar kamu mendapat keberuntungan. (Q.S. Al-Maidah: 90)

Jika ayat tersebut dikaji melalui perspektif Ushul Fiqh, maka lafadz fajtanibuhu adalah shighat yang digunakan al-Quran yang bermakna larangan atau haram. Oleh karena itu, maisir hukumnya haram.

Larangan maisir tersebut mempunyai maqashid, yaitu menghindari kemalasan kerja yang diakibatkan oleh impian dan spekulasi.

Selain itu, maisir juga mengakibatkan terjadinya permusuhan di antara sesama karena illat maisir adalah taruhan. Berdasarkan maqashid ini, maka tidak setiap permainan itu diharamkan, akan tetapi permaianan yang menyebabkan maqashid tersebut yang diharamkan. Permainan tersebut bisa dikategorikan maisir jika memenuhi beberapa unsure, di antaranya adalah:

a. Taruhan dan mengadu nasib sehingga pelaku bisa menang atau kalah.

b. Seluruh pelaku maisir mempertaruhkan hartanya, pelaku judi mempertaruhakn hartanya tanpa imbalan. Dalam bisnis, yang dipertaruhkan adalah kerja dan resiko bisnis.

c. Pemenang mengambil hak orang lain yang kalah, karena setiap pelaku juga tidak member manfaat kepada lawannya. Ia mengambil sesuatu dan kalah tidak mengambil imbalannya.

d. Pelaku berniat mencari uang dengan mengadu nasib. Tidak ada target lain. Hal ini untuk membedakan dengan permainan yang tidak menjadi sarana mencari uang. ${ }^{33}$

\section{Maqashid larangan ihtikar}

Ihtikarmenurut madzhab Hambali dan Syafi'i bahwa menimbun barang yang telah dibeli pada saat harga melambung tinggi untuk dijualnya kembali dengan harga yang lebih tinggi pada saat dibutuhkan oleh masyarakat. Sementara itu, ada juga yang memaknai ihtikar/monopoli (rekayasa pasar dalam supplay) adalah pengurangan supplyyang dilakukan oleh penjual atau produsen untuk menaikkan harga jual produknya.

Ihtikar biasanya penjual membuat entri barriers, yakni menghambat penjual atau produsen lain masuk ke pasar agar ia menjadi pemain tunggal di pasar (monopoli). Praktek ihtikar tersebut jelas diharamkan dalam Islam, sebagaimana yang dijelaskan oleh Rasulullah dalam sabdanya:

Artinya: diriwayatkan dari Abi Umamah, ia berkata, Rasulullah Saw melarang memonopoli makanan.

Selain itu, juga hadis Sa'id bin al-Musayyib yang artinya:

Artinya: diriwayatkan dari Sa'id bin al-Musayyib, ia berkata: Rasulullah Saw bersabda: barangsiapa 
melakukan monopoli, maka ia berdosa.

Dari kedua hadis tersebut, dapat diambil kesimpulan bahwa Islam melarang praktek monopoli. Dalam hal ini, Abu Yusuf dan As-Syaukani berpendapat bahwa setiap praktek monopoli itu terlarang, baik untuk kebutuhan primer maupun kebutuhan sekunder, karena hadis tersebut tidak membedakan obyek monopoli.

'illat ihtikar adalah dapat memberikan kemadharatan atau bahaya bagi masyarakat. Hal ini dikarenakan produk dan barang tersebut sangat dibutuhkan masyarakat Ketentuan ini sesuai dengan maqashid larangan ihtikar karena dapat menimbulkan bahaya bagi kepentingan masyarakat. Masyarakat kesulitan mendapatkan barang atau produk dan harganya semakin mahal. Praktek tersebut tentu berlawanan atau kontradiktif dengan transaksi bisnis yang harus mengikuti kaidah supply and demand secara alami atau natural sebagaimana dijelaskan di dalam al-Quran surat al-Hasyr ayat 7:

Artinya: Supaya harta itu jangan beredar di antara orang-orang kaya saja di antara kamu. (Q.S. al-Hasyr: 7)

Ayat tersebut, menjelaskan bahwa salah satu tujuan harta adalah harta itu bisa menyebarr dan dinikmati oleh semua kalangan atau masyarakat. praktek ihtikar tersebut jelas bertentangan dengan tujuan harta. Jika produk tertentu dimonopoli sehingga menjadi langka dan harga semakin tinggi, maka jelas ini mengakibatkan banyak kemudaratan atau mafsadah yang jelas bertentangan dengan maqashid syariah yang tujuan utamanya adalah kemaslahatan. Dengan demikian, larangan praktek ihtikar ini mempunyai maqashid untuk menghindari bahaya dan kerugian masyarakat yang diakibatkan dari ihtikar.

Berdasarkan maqashid tersebut, maka ihtikar diharamkan apabila memenuhi beberapa syarat, di antaranya adalah:

a. Mengusahakan terjadinya kelangkaan barang yang dilakukan dengan cara menimbun stok atau entry barriess.

b. Menjual barang dengan harga yang lebih tinggi dibanding dengan harga sebelum munculnya kelangkaan.

c. Mengambil keuntungan yang lebih tinggi dibandingkan keuntungan sebelum komponen satu dan dua dilakukan. ${ }^{34}$

\section{Maqashid larangan Bai'Najasy'}

Bai' Najasy' disebut juga dengan rekayasa pasar dalam demand, yaitu apabila produsen membuat ermintaan palsu yang seolah-olah telah ada banyak permintaan pada suatu produk sehingga harga jual produk itu menjadi naik. Contoh praktek Bai' Najasy'adalah dalam bursa valas, bursa saham, dan lain-lain. Metode yang dilakukan biasanya bermacam-macam, bisa dengan menyebarkan isu, melakukan order pembelian sampai benar-benar melakukan pembelian 
pancingan agar tercipta sentiment pasar untuk ramai-ramai membeli saham tertentu. Jika harga sudah naik, maka yang bersangkutan akan melakukan aksi ambil untung dengan menjual saham atau mata uangnya, sehingga mendapatkan untung yang besar.

Praktek jual beli tersebut jelas dilarang di dalam Islam, sebagaiman dijelaskan dalam hadis Rasulullah dari Ibnu Abbas yang artinya:

Dari ibnu Umar ra., bahwa Rasulullah Saw melarang melakukan najasy.

Larangan najasy tersebut mempunyai maqashid untuk menghindari atau mencegah terjadinya penipuan yang bisa mengakibatkan kezaliman atau kerugian di antara pihak-pihak yang bertransaksi maupun pihak lainnya. Hal ini dikarenakan di dalam praktek Bai'Najasy' ada unsur penipuan yang merusak harga pasar dengan cara manipulasi atau rekayasa.

Jika dilihat dari persepketif ekonomi, praktek Bai' Najasy' tersebut juga tidak diperbolehkan karena penjual menyuruh orang lain untuk memuji barangnya atau menawar dengan harga tinggi agar orang lain tertarik untuk membeli. Pihak penawar sendiri juga tidak bermaksud untuk membeli barang tersebut, hanya ingin menipu orang lain agar tertarik untuk membeli. Mereka sebelumnya sudah bersepakat untuk membeli dengan harga tinggi agar ada pembeli yang sesungguhnya dengan harga yang tinggi pula dengan maksud untuk ditipu. Akibatnya, terjadi "permintaan palsu" yang dapat menyebabkan kerugian atau kezaliman.

\section{Simpulan}

Formulasi bisnis halal thayyib dalam perspektif maqashid syari'ah kontemporer Jasser Auda merupakan penjabaran dari salah satu maqashid syariah, yaitu untuk menjaga dan memenuhi hajat dan maslahat akan harta (hifdzul mal). Ada beberapa maqashid dalam transaksi bisnis yang meliputi 3 tingkatan, yaitu: Maqashid 'Ammah yang mengedepankan keadilan, Maqashid Khassah yang mengedepankan kesejahteraan masyarakat, bangsa, bahkan umat manusia, dan Maqashid Parsial yang menyatakan bahwadibalik setiap transaksi bisnis yang halal thayyib pasti mempunyai maksud tertentu yang orientasinya adalah terwujudnya kemaslahatan, bukan mafsadah.

Etika bisnis halal thayyib dalam perspektif maqashid syariah kontemporer Jasser Auda meliputi adanya larangan mengandung unsur (1) riba,(2) gharar, (3) maisir, (4) ihtikar, dan(5) bai' najasy'dalam bisnis. Maqashid dari larangan riba adalah untuk menghindari terjadinya praktek kezaliman terhadap pelaku bisnis. Sedangkan keharaman riba buyu' memiliki maqashid, yaitu menghindarkan gharar dalam transaksi jual beli. Maqashid dari larangan gharar adalah untuk mengihindari kemudaratan, kerugiaan, ketidak adilan dan kezaliman dalam transaksi bisnis. Sementara itu, larangan maisir mempunyai maqashid untuk menghindarkan kemalasan kerja karena impian dan spekulasi. Sedangkan larangan praktek ihtikar ini mempunyai maqashid 
untuk menghindari bahaya dan kerugian untuk menghindari terjadi "permintaan palsu" masyarakat yang diakibatkan dari ihtikar. yang dapat menyebabkan kerugian atau Larangan bai' najasy' mempunyai maqashid kezaliman.

\section{DAFTAR PUSTAKA}

\section{Buku}

Aminudin dan Zainal Asikin, Pengantar Penelitian Hukum, Raja Grafindo Persada, Jakarta, 2004

Arikunto, Suharsimi, Prosedur Penelitian, PT Rineka Cipta, Jakarta, 2006

Auda, Jasser.Al-Maqashid untuk Pemula, Yogyakarta, UIN Suka Press, 2013

Dimyati, Moh. Penelitian Kualitatip,IKIP Malang, Malang, 1990

Hadi, Sutrisno, Metodologi Research, tp, Yogyakarta

Fauziyah, Nur Dinah, Muawanah, dan Sundari. Etika Bisnis Syariah,Literasi Nusantara, Malang, 2019

Kementerian Agama RI, Tafsir al-Quran Tematik: Pembangunan Ekonomi Umat,Jakarta: Lajnah Pentashihan Mushaf al-Quran Badan Litbang dan Diklat Kementerian Agama RI, 2012 Machdhoni, Metode Penelitian Untuk Ilmu Ekonomi,UMM Press, Malang, 1993

Marzuki, Mahmud Marzuki, Penelitian Hukum, Jakarta: Kencana Prenada Media Group, 2005

Miles, Matthew B. dan A. Michael Huberman,Analisis data Kualitatif, terj. Tjetjep Rohendi Rohidi,UI Press, Jakarta: 1992
Mufid, Moh. Maqashid Ekonomi Syariah,Intrans Publishing, Malang, 2018

Nazir, Moh, Metode Penelitian, Ghali Indonesia, Jakarta, 2005

Rivai, Veithzal, Andi Buchari, Islamic Economics, Bumi Aksara, Jakarta: 2013 Sahroni, Oni, dan Adiwarman A. Karim. Maqashid Bisnis dan Keuangan Islam: Sintesis Fiqih dan Ekonomi,Depok, Rajawali Pers, 2017

Santosos, Mudji, Hakekat, Peranan, dan Jenisjenis Penelitian, serta Pola Penelitian pada Pembangunan Lima Tahun ke VI, dalam Imron Arifin (ed), Penelitian Kualitatif dalam Ilmu-Ilmu Sosial dan Keagamaan, Kalimasahada Press, Malang, 1996

Wiyono, Bambang Budi, Metodologi Penelitian:Pendekatan Kuantitatif, Kualitatif, dan Action Research, Fakultas Ilmu Pendidikan UM, Malang, 2007

\section{Jurnal}

Ardi, Mulia, Diskursus Etika Bisnis Islam dalam Dinamika Bisnis Kontemporer, AN-NISBAH, Vol. 01, No. 02, April 2015 
Darmawati, Etika bisnis dalam perspektif Islam: Eksplorasi Prinsip Etis al-Quran dan Sunnah, E-Journal STAIN Samarinda, diakses pada tanggal 15 Maret 2020

Gumanti, Retna. Maqasid Al-Syariah Menurut Jasser Auda (Pendekatan Sistem dalam Hukum Islam), Jurnal Al-Himayah Volume 2 Nomor 1 Maret 2018

Hakim, Muhammad Lutfi,. Pergeseran Pradigma Maqashid Syariah dari Klasik sampai Kontemporer, Manahij, VolX No 1 Juni 2016

Hidayatullah, Haris, Etika Bisnis Dalam Prespektif Al-Qur'an: Upaya Membangun Bisnis Yang Islami Untuk Menghadapi Tantangan Bisnis Di Masa Depan, Ejournal UNIPDU Jombang, diakses pada 15 Maret 2020

Khoiruddin, Etika Pelaku Bisnis dalam Perspektif Islam,jurnal ASAS, Vol. 7, No. 1, Januari 2015

Irsadunas, dkk, Tinjauan Etika Bisnis Islam dalam Pengelolaan Corporate social Responsibility, JEBI(Jurnal Ekonomi dan Bisnis Islam)-Volume 3, Nomor 2,Juli-Desember 2018
Matnin, Konsepsi Etika Bisnis dalam al-Quran dan Sunnah, E Journal STAI Al-Khairat Pamekasan, diakses pada 15 Maret 2020

Nurdin, Irfan B., Sistem Ekonomi Islam Berlandaskan Etika Bisnis, jurnal AD-DEENAR Jurnal Ekonomi dan Bisnis

Nurhadi, Maqashid Ammah dan Khashah Operasional Bank Syariah, Jurnal Ekonomi Islam Volume 9, Nomor 2, November 2018

Shidiq, Ghafar, Teori Maqashid Syariah dalam Hukum Islam, Sultan Agung Vol. XLIV No. 118 Juni-Agustus 2009.

Supriadi, Akhmad. Sistem Sebagai Filsafat (Tawaran Baru Jasser Auda Bagi Pengembangan Hukum Islam Kontemporer),Jurnal Studi Agama dan Masyarakat Volume 13, Nomor 2, Desember 2017

Syukron, Ahmad,Membongkar Konsep Etika Bisnis dalam al-Quran:Perspektif Epistimologis, E Journal STAIN Pekalongan, diakses pada tanggal 15 Maret 2020 